UDC 339.92

DOI 10.33111/iep.2019.31.06_eng

\title{
Organizational and Institutional Directions of Strengthening of Ukraine's Position in International Investment Markets
}

OLENA LiUTAK,
OLENA BAULA

\begin{abstract}
The article describes the main aspects of investment environment of the country and organizational and institutional directions of Ukraine's position in international investment activity optimization. Modern investment flows of Ukraine are analyzed from the point of view of institutional support and geography. The description of modern processes of share capital and debt securities movement in current circumstances is outlined, with determination of preconditions and consequences of further integration of our country into global investment flows. It is proven that the volumes of share capital of non-residents and foreign direct investment are increasing. This proves the stabilization of macroeconomic indicators and foreign interest in receiving income from our country's economic potential, in particular, the volumes of investment in domestic government bonds. There was formed the economic and mathematical model of the impact of investment on the development of our country's economic strength and GDP growth. The priority to involve all organizational and institutional directions of Ukraine's positions optimization in international investment activity in order to increase the incoming investment flows of modern transformations of the global investment process is argued. Ukraine's position in the international ratings, reflecting the institutional effectiveness of the domestic policy of foreign investments attraction in the sphere of business activity is analysed. The systematic view of foreign investment barriers in Ukraine, based on results of foreign investors survey by the European Business Association, Dragon Capital and the Center for Economic Strategies is set out. It has been determined that the main ways for increasing the institutional effectiveness of investment policy in Ukraine in the context of globalization and internationalization of the world economy should be real, but not declarative improvement of the investment environment, reduction of bureaucracy for investors, simplification of regulatory and registration requirements and the adoption of significant steps of investors' rights revealing protection. The characteristic of modern processes regarding the distribution of dividend payment practice and the legislatively held responsibility of issuer for received funds from investors who are able to launch the mechanism of stock market instruments use, turning the personal savings into investments, and spreading fair competition among investors is given. The objectives and measures of the organizational and institutional mechanism of effectiveness improvement of the domestic policy of foreign investments attraction in business activities are substantiated, the necessity of fundamental reforms in the direction of the improvement of the country's innovation and investment development, the "reform pyramid" and the mechanism of its realization are outlined.
\end{abstract}

\footnotetext{
* This article was translated from its original in Ukrainian.

${ }^{1}$ Liutak Olena Mykolayivna - Doctor of Economics, Professor, Professor at the Department of International Economic Relations, Lutsk National Technical University. Sphere of scientific interests: global institutionalization of services, international tourism, regulation of the development of world markets for food and non-food products; innovation-investment potential, regional policy of cross-border cooperation, tourist-recreational potential of the cross-border region. E-mail: olenalutak@gmail.com.

Baula Olena Viktorivna - Ph.D. (Economics), Associate Professor, Associate Professor at the Department of International Economic Relations, Lutsk National Technical University. Sphere of scientific interests: international investment activity, international economic integration, globalization of economic development, globalization of financial markets. E-mail: o.baula@lntu.edu.ua.
}

IEP, № 31, (2019) pp. 146-166

(C) Olena Liutak, Olena Baula, 2019 «All rights reserved»

ISSN 1811-9832/2019/№ 2 (31) 
KEY WORDS: investments, investment environment, share capital, debt securities, institutional effectiveness of the investment policy, international ratings, institutional and organizational basis, business activity.

\section{Introduction}

One of the forms of international economic relations is foreign investment, which becomes increasingly importance for economic development and facilitates macroeconomic stabilization policy. The experience of many countries of the world shows the expediency of foreign investments attraction both for the country's economy way out of the crisis and ensuring its sustainable development. But in order to attract foreign investments into the national economy, the state must also accommodate with investors - to develop a system of protection (guarantee and insurance) of investments.

Scientists argue that direct foreign investments began to play an important role in the international economy after World War II. The first theories to explain the role of direct foreign investments occurred as a result of growing activity of subsidiaries of US based companies on the markets of Europe and Latin America in the 1950s and 1960s of the XX century. Since then, volumes of direct foreign investments have steadily increased, which has led to the urgent need to study the features of capital movement process on world markets ${ }^{2}$.

Under the conditions of financial imbalance, rising public debt, reduction of real income level of the population, stagnation of innovation activity, observed in Ukraine, as well as under the influence of integration and globalization processes in the modern world economy, investments obtain an exceptional importance for the domestic economy. In modern times, the possibility of integrating of Ukraine into the European social and economic area, competitive growth of domestic enterprises, as a primary element of the national economy depends on the efficiency of investment policy implementation. In order to strengthen the internal investment activity of domestic enterprises and attraction of foreign investors, the state must ensure the implementation of a reasonable investment policy to ensure a business-enabling environment in the country, the development of infrastructure support of investment processes, etc.

A major contribution to the development of international investment theory was made by foreign and domestic scientists: I. Blank ${ }^{3}$, Z. Bodi ${ }^{4}$,

\footnotetext{
${ }^{2}$ Byrka M.I. Teoretyko-metodolohichni pidkhody do analizuvannia priamykh inozemnykh investytsii $v$ konteksti yikh zaluchennia. http://jrnl.nau.edu.ua/index.php/SR/article/view/4701/0 [In Ukrainian].

${ }^{3}$ Blank I.A. Capital Management (rus. Upravleniye ispolzovaniyem kapitala). K.: «Nika-Tsentr». 2000.656 p. [In Russian]; Blank. I.A. Financial resources management (rus. Upravleniye finansovymi resursami). M.: Omega-L. Elga. 2011. 768 p. [In Russian].
} 
I. Buzko, O. Vovchak, N. Rushchyshyn, I. Andrushkiv, I. Buchko ${ }^{6}$, V. Heiets ${ }^{7}$, T. Huskova ${ }^{8}$, L. Dashutyna, V. Turchin ${ }^{9}$, A. Duka ${ }^{10}$, J. Keynes ${ }^{11}$, N. Kyselova ${ }^{12}$, F. Kotler ${ }^{13}$, D. Lukianenko ${ }^{14}$, T. Maiorova ${ }^{15}$, Yu. Makohon ${ }^{16}$, N. Navrotska ${ }^{17}$, L. Petkova ${ }^{18}$, M. Porter ${ }^{19}$, A. Thompson ${ }^{20}$, W. Sharp, H. Aleksander, G. Bailey ${ }^{21}$, and others.

At the same time, despite the presence of detailed and thorough scientific achievements of scientists of different years, the problematics of the institutional effectiveness of the domestic policy of foreign investments attraction to the sphere of business activity have not been sufficiently studied. There are needed further investigation the organizational and institutional directions of optimization of Ukraine's positions in international investment activity and identification of worldwide trends in the formation of the international investment environment.

${ }^{4}$ Alex Kane, Alan Marcus Zvi Bodie, Investment Principles. Transl. from Eng. 4 edition. M.: Viliams. 2008. 984 p.

Buzko I.R., Chyzh V.I., Tyshchenko A.Yu. Investytsiina polityka u hlobalnomu vymiri: formuvannia ta realizatsiia: monohrafiia. Skhidnoukr. nats. un-t im. V. Dalia. Luhansk: Vyd-vo SNU im. V. Dalia, 2011. 192 p. [In Ukrainian].

${ }^{6}$ Vovchak O.D., Rushchyshyn N.M., Andrushkiv I.P., Buchko I.Ye. Investytsiine kredytuvannia: navch. posib. 2-he vyd., pererobl. i dopovn. K.: Znannia, 2013. 227 p. [In Ukrainian].

7 Heiets V. Podolannia kvazirynkovosti - shliakh do investytsiino oriientovanoi modeli ekonomichnoho zrostannia. Ekonomika Ukrainy. 2015. No. 6. pp. 4-17. [In Ukrainian].

8 Guskova T.N. Assessment of investment attractiveness of objects by statistical methods (rus. Otsenka investitsionnoy privlekatelnosti obyektov statisticheskimi metodami). M.: GASBU. 2009. 278 p. [In Russian].

${ }^{9}$ Dashutyna L.O. Osoblyvosti investuvannia transnatsionalnykh korporatsii u mizhnarodnomu biznesi. Visnyk Sumskoho natsionalnoho ahrarnoho universytetu. Seriia : Ekonomika i menedzhment. 2012. Vyp. 8. pp. 179-183. http://nbuv.gov.ua/UJRN/Vsna ekon 2012840 [In Ukrainian].

${ }^{10}$ Duka A.P. Teoriia ta praktyka investytsiinoi diialnosti. Investuvannia: Navchalnyi posibnyk. K.: Karavela, 2014. 432 p. [In Ukrainian].

${ }^{11}$ Keynes J.M. General theory of employment interest and money. M .: Helios ARV, 1999.352 p. [In Russian].

${ }^{12}$ Kiseleva N.V. Investment activity: a training manual. M.: KNORUS, 2008. 432 p. [In Russian].

${ }^{13}$ Kotler F., Kartadzhaiia Kh., Yanh D. Pryvlechenye ynvestorov: marketynhovbii pokhod k poysku ystochnykov fynansyrovanyia. Per. s anhl. M.: Alpyna Byznes Buks, 2009. 194 p. [In Russian].

${ }^{14}$ Lukianenko D. H., Hubskyi B. V., Mozghovyi O. M. ta in. Mizhnarodna investytsiina diialnist: pidruchnyk zza red. D.H.Lukianenka. K.: KNEU, 2003. 387 p. [In Ukrainian].

15 Maiorova T.V., Dyba V.M. Formuvannia investytsiinoho kapitalu $\mathrm{v}$ umovakh hlobalnykh vyklykiv. Investytsii: praktyka ta dosvid. 2011. No. 18. pp. 4-8 [In Ukrainian].

${ }^{16}$ Makohon Yu.V., Lysenko K.V. Ukraine's Investment Attractiveness in Conditions of Global Transformations. Theoretical and practical aspects of intellectual power. 2012. VIP. 1, T. 1. pp. 7-13; Makohon Yu.V., Ivankova D.R. Teoretychni aspekty hlobalnoi investytsiinoi diialnosti. Ekonomichnyi visnyk Natsionalnoho tekhnichnoho universytetu Ukrainy «Kyivskyi politekhnichnyi instytut». 2014. No. 11. pp. 481-486. http://nbuv.gov.ua/ UJRN/evntukpi_2014_11_76 [In Ukrainian].

${ }^{17}$ Navrotska N.A. Transformatsiia svitovoho investytsiinoho prostoru v umovakh hlobalizatsii. Ekonomichnyi chasopys KhKhI st. 2013. No. 3-4 (1). pp. 13-16. http://nbuv.gov.ua/UJRN/ecchado_2013_3-4\%281\%29_5 [In Ukrainian].

${ }^{18}$ Petkova L.O. Dyversyfikatsiia mizhnarodnykh investytsiinykh stratehii v umovakh hlobalnykh strukturnykh zrushen. Finansovyi prostir. 2012. No. 4 (8). pp. 45-48. [In Ukrainian].

${ }^{19}$ Porter, M. E. Competitive Strategy: Techniques for Analyzing Industries and Competitors. - New York: The Free Press, 1980 (2nd ed.). New York: Free Press, 1998. 397 p.

${ }^{20}$ Thompson Jr. Arthur A., Strickland III A.J. Strategic Management. Concepts and situations for analysis. M.: Publishing. Williams House, 2006. - 928 p. [In Russian].

${ }^{21}$ Sharp W.F., Alexander G.J., Bailey J.V. Investments. M.: Infra-M, 2001.1028 p. [In Russian]. 
The main objective of the research is to reveal the main aspects of Ukraine's investment environment, to analyze the position of Ukraine in the international ratings, reflecting the institutional effectiveness of the domestic policy of foreign investments attraction to the sphere of business activity and obstacles to foreign investments in Ukraine, as well as to identify directions for improving of innovation and investment development of Ukraine.

\section{Investment flows of Ukraine}

Effective reform of our country's economy, its structural transformation with assurance of qualitative development, renewal of market and social infrastructure are not possible without adequate investments, i.e. without appropriate investment. The more active it is, the faster the pace of growth and effective market transformations. Among all investment entities, a special role belongs to the state, which acquires the status of entity through its institutions, companies and corporations. As a consequence, the state can participate in organizational and institutional support both through the public sector of the economy and through the authorities, institutions that regulate an investment activity ${ }^{22}$.

In terms of foreign investment, the domestic economy is characterized by a significant impact of offshore zones on Ukraine's participation in the international capital movement. The real economic situation and the state of direct foreign investments attraction in Ukraine significantly complicate an investment activity due to the high level of shadowing, the regulation of the processes of revitalization of entrepreneurial activity. The available volume of investments does not provide the precondition for the economic growth and even full reproduction of their current state. Not only the general state of the country's economy affects the investment attractiveness, but also the conduct of business, including the ratio of government intervention and the level of corruption ${ }^{23}$. The change of investment environment is most clearly demonstrated by the investment dynamics, especially direct investments, which is considered to be an indicator of the confidence level change and country rating.

According to the Ministry of Finance of Ukraine for 2002-2018 years the highest amount of direct investments inflows to Ukraine were observed in 2008 (USD $10913 \mathrm{mln}$ ) and the lowest amount in 2014 (USD $410 \mathrm{mln}$ ) (Table 1).

\footnotetext{
22 Revutska N. Suchasni instrumenty zaluchennia inozemnoho kapitalu. Tsinni papery Ukrainy. 2014 . No 9. pp. 54-58. [In Ukrainian].

${ }^{23}$ Gerzanych V.M. Major Disadvantages and Problems of Attracting Foreign Investment in Ukraine // Effective Economics: Electr. Sciences. profession. view. 2014. No. 4. http: //www.economy.nayka. com.ua/n=4\&y=2014 [In Ukrainian].
} 
Table 1

DIRECT FOREIGN INVESTMENTS (SHARE CAPITAL), ATTRACTED TO THE DOMESTIC ECONOMY AND DIRECTED ABROAD IN 2002-2018 ${ }^{24}$

\begin{tabular}{|c|c|c|c|c|c|c|}
\hline \multirow[b]{2}{*}{ Years } & \multirow{2}{*}{$\begin{array}{c}\text { Direct } \\
\text { investments } \\
\text { in Ukraine, } \\
\text { USD mln. }\end{array}$} & \multirow{2}{*}{$\begin{array}{l}\text { Absolute } \\
\text { Deviation, } \\
\text { USD mln. }\end{array}$} & \multirow{2}{*}{$\begin{array}{c}\text { Direct } \\
\text { investments } \\
\text { from } \\
\text { Ukraine, } \\
\text { USD mln. }\end{array}$} & \multirow{2}{*}{$\begin{array}{l}\text { Absolute } \\
\text { Deviation, } \\
\text { USD mln. }\end{array}$} & \multicolumn{2}{|c|}{ Net balance } \\
\hline & & & & & $\begin{array}{l}\text { Absolute, } \\
\text { USD mln. }\end{array}$ & relative, \% \\
\hline 2002 & 693 & & -5 & & +698 & \\
\hline 2003 & 1424 & +731 & 13 & +18 & +1411 & +102.1 \\
\hline 2004 & 1715 & +291 & 4 & -9 & +1711 & +21.3 \\
\hline 2005 & 7805 & +6093 & 275 & +271 & +7533 & +340.3 \\
\hline 2006 & 5604 & -2204 & -133 & -408 & +5737 & -23.8 \\
\hline 2007 & 9891 & +4287 & 673 & +806 & +9218 & +60.7 \\
\hline 2008 & 10913 & +1022 & 1010 & +337 & +9903 & +7.4 \\
\hline 2009 & 4816 & -6097 & 162 & -848 & +4654 & -53.0 \\
\hline 2010 & 6495 & +1679 & 736 & +574 & +5759 & +23.7 \\
\hline 2011 & 7207 & +712 & 192 & -544 & +7015 & +21.8 \\
\hline 2012 & 8401 & +1194 & 1206 & +1014 & +7195 & +2.6 \\
\hline 2013 & 4499 & -3902 & 420 & -786 & +4079 & -43.3 \\
\hline 2014 & 410 & -4089 & 111 & -309 & +299 & -92.7 \\
\hline 2015 & 2961 & +2551 & -51 & -162 & +3012 & +907.4 \\
\hline 2016 & 3284 & +323 & 16 & +67 & +3268 & +8.5 \\
\hline 2017 & 2202 & -1082 & 8 & -8 & +2194 & -32.9 \\
\hline 2018 & 2355 & +153 & -5 & -13 & +2360 & +7.6 \\
\hline
\end{tabular}

As we can see, the largest increase of net balance of direct foreign investments accounted for 2015, but this increase occurred against the background of year 2014, which was characterized by the lowest indicators of direct foreign investments attraction in Ukraine over the period of 2002-2018 years. Analyzing the indicators of direct foreign investments inflows in the Ukrainian economy over the last 17 years, we can see that there is actually no regularity: there has been a gradual increase of direct foreign investments attraction in Ukraine's economy during 2002-2008, and there has been a periodic increase and decrease of this indicator due to the global economic crisis since 2009, the military aggression of the Russian Federation, political uncertainty. All factors

\footnotetext{
${ }^{24}$ Foreign direct investment. URL: https://index.minfin.com.ua/en/economy/fdi/2018/ [In Ukrainian].
} 
have significantly undermined the foundations of a favorable investment environment and, despite the considerable interest of foreign investors in the development of their business in our country, have constrained the volume of incoming investment flows.

The current trend of revitalization of the international investment activity indicates an increase in financial flows to our country, in particular, according to the report of National Bank, Ukraine received USD 0.8 billion of direct foreign investments in the first quarter of 2019. In 2018, their volume exceeded USD 2 billion 355 million, it is more for 153 million than a year earlier ${ }^{25}$.

As of the beginning of 2019, EU countries are the largest investors in Ukraine's economy. In 2018 the TOP-10 countries according to the volumes of direct investments in Ukraine are as follows: Cyprus, Netherlands, United Kingdom, Germany, Switzerland, Virgin Islands, Russian Federation, Austria, France, Poland. In 2018, according to the Ministry of Finance, the majority of direct foreign investments in Ukraine is the return of Ukrainian funds from offshore and the recapitalization of banks ${ }^{26}$.

The globalization of financial markets has transformed financial relations into an independent factor of the world economy development, where offshore capital can be regarded as a special form of financial capital movement. The internationalization of world finance was the reason for the offshore financial centers appearance: national capital that went beyond and wanted to "get away" from rigid national regulation and create favorable conditions for development.

Offshore operations have a significant place in foreign economic operations of Ukraine. The legislation of our country does not prohibit the creation of companies in offshore areas. The volume of such operations is increasing annually. The share of offshore investments remains unchanged and ranges from $40-44 \%$ for the study period. There are three offshore zones among the largest investors in Ukraine: Cyprus, Virgin Islands and Switzerland. Regarding to the outflow of Ukrainian capital to offshore zones, almost 95\% of direct investments from Ukraine come into the worldwide national economy to offshore zones ${ }^{27}$. Cyprus is the main country, an offshore zone, from which direct investments come to Ukraine and where they come from.

\footnotetext{
${ }^{25}$ Why foreign investments are in no hurry to Ukraine. URL: https://minfin.com.ua/en/2019/05/14/37746973/. [In Ukrainian].

26 The State Statistics Committee named the leading countries for investments in Ukraine. https://www.rbc.ua/eng/news/gosstat-nazval-strany-lidery-investitsiyam-1551374343.html. [In Ukrainian].

${ }^{27}$ Ukraine's State Statistics Committee Data. http://www.ukrstat. gov.ua/ [In Ukrainian].
} 
As relating to operations between Ukraine and Cyprus, it can be affirmed, that a significant percentage of the capital invested in Ukraine is reinvested Ukrainian capital, which can be said that it was invested in the way of the shadow economy.

Ukraine is in the ratings of thirty countries with the most favorable environment for the offshore. There is the most active interaction with such offshore zones as Cyprus, Virgin Islands and Switzerland. Reinvested Ukrainian capital is a large part of the investments that come into Ukraine. With the aim to strengthen the control over operations with the offshores, the Cabinet of Ministers of Ukraine made a list of operational offshores, and the operations should be monitored and are liable to tax. It is difficult to predict what kind of offshore zones will be in the future, but it can be assumed that offshore activities will be legalized and "black" offshores will be replaced by serious and civilized zones, that will set a goal to conduct activities within the limits of the law, but not crime. However, in our view, radical measures against "black" offshores, such as their liquidation, will not bring the expected success, because at this stage of development, states have sufficient information about such zones and, if they wish, can carry out limited control over their activities, and in case of liquidation, the world economy would become more shadowing, and new little-known, uncontrolled territories would appear.

Describing the structure of share capital and debt instruments in Ukraine's economy in 2017-2018 years (Table 2), we can point out the leading role of EU countries, in particular in 2017 their part was $75 \%$, and in $2018-76,4 \%$. As a whole, the volume of non-resident share capital and direct foreign investments are increasing, which indicates the stabilization of macroeconomic indicators and the interest of foreigners in receiving of income from the use of our country's potential. Volume of investments in domestic government loan bonds by non-residents whose buy-out program have been implemented and have led to a stabilization of the exchange rate are particularly significant.

This trend is formed by the high profitability of Ukrainian securities, state guarantees and the ability to use the projected rapid rate of development of the country and increasing of its competitiveness. Ukraine is one of the countries in the European space whose potential is greatly underestimated and untapped. The world market conditions, theses on significant reforms, the opportunity to invest in the land market make our country an important investment object and today it is an instrument for optimizing position of Ukraine in international investment activity. 


\section{DIRECT INVESTMENTS (SHARE CAPITAL AND DEBT INSTRUMENTS) IN THE ECONOMY OF UKRAINE IN 2016-2018 8}

\begin{tabular}{|c|c|c|c|c|c|c|c|}
\hline \multirow{3}{*}{ Indicators } & \multirow{3}{*}{2016} & \multirow{3}{*}{2017} & \multirow{3}{*}{2018} & \multicolumn{4}{|c|}{ Including } \\
\hline & & & & \multicolumn{2}{|c|}{ EU countries } & \multicolumn{2}{|c|}{ other countries } \\
\hline & & & & 2017 & 2018 & 2017 & 2018 \\
\hline $\begin{array}{l}\text { Direct investments of } \\
\text { non-residents in Ukraine } \\
\text { (share capital and debt } \\
\text { instruments) as of } \\
\text { January } 01 \text { of the } \\
\text { reporting year }\end{array}$ & 40005.3 & 38796.9 & 40020.9 & 30071.0 & 31114 & 8725.9 & 8906.0 \\
\hline $\begin{array}{l}\text { Share capital of non- } \\
\text { residents as of January } \\
01 \text { of the reporting year }\end{array}$ & 32122.5 & 31230.3 & 31606.4 & 23427.7 & 24145 & 7804.6 & 7461.2 \\
\hline $\begin{array}{l}\text { Received share capital of } \\
\text { non-residents }\end{array}$ & 4405.9 & 2511.1 & 2869.9 & 1631.7 & 2200.9 & 879.4 & 669.0 \\
\hline $\begin{array}{l}\text { Retired share capital of } \\
\text { non-residents }\end{array}$ & -904.2 & -759.0 & -968.1 & -564.2 & -678.3 & -194.8 & -289.8 \\
\hline $\begin{array}{l}\text { Other changes of share } \\
\text { capital value of non- } \\
\text { residents (change of } \\
\text { value, loss, } \\
\text { reclassification of } \\
\text { investments, etc.) }\end{array}$ & -2687.8 & -326.4 & -1216.3 & 236.0 & -925.1 & -562.4 & -291.2 \\
\hline $\begin{array}{l}\text { Share capital of non- } \\
\text { residents }\end{array}$ & 32936.4 & 32656.0 & 32291.9 & 24729.2 & 24742 & 7926.8 & 7549.2 \\
\hline $\begin{array}{l}\text { Debt instruments (credit } \\
\text { and loan arrears, trade } \\
\text { credit obligations and } \\
\text { other direct investor } \\
\text { obligations) as of } \\
\text { January } 01 \text { of the } \\
\text { reporting year }\end{array}$ & 7882.8 & 7566.6 & 8414.5 & 6645.3 & 6969.7 & 921.3 & 1444.8 \\
\hline $\begin{array}{l}\text { Non-resident direct } \\
\text { investments in Ukraine } \\
\text { (share capital and debt } \\
\text { instruments) as of } \\
\text { December } 31 \text { of the } \\
\text { reporting year }\end{array}$ & 40530.1 & 41104.6 & 40514.1 & 31782.1 & 31559.0 & 9322.5 & 8955.1 \\
\hline
\end{tabular}

Confirming the significant impact of investment activity on the development of economic potential of our country, we create a

${ }^{28}$ State Statistics Service. Economic statistics. Foreign economic activity. Investment in foreign economic activity. http://www.ukrstat.gov.ua/ [In Ukrainian]. 
regression model for the impact of investments in capital asset in $\mathrm{UAH}$ million. (independent factor X) on the GDP of Ukraine in UAH million (resulting factor B) in 2000-2018.

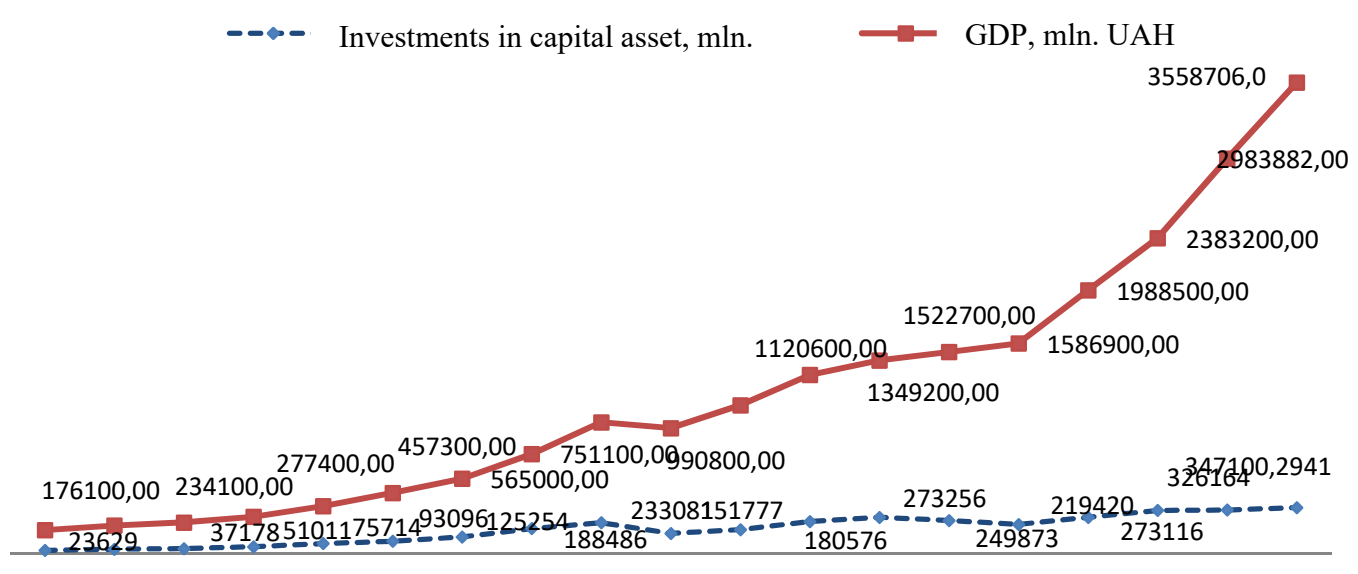

2000200120022003200420052006200720082009201020112012201320142015201620172018

Fig. 1. Initial data for model construction in years 2000-2018.

\section{Correlation field}

$\mathrm{UAH}$, thousand

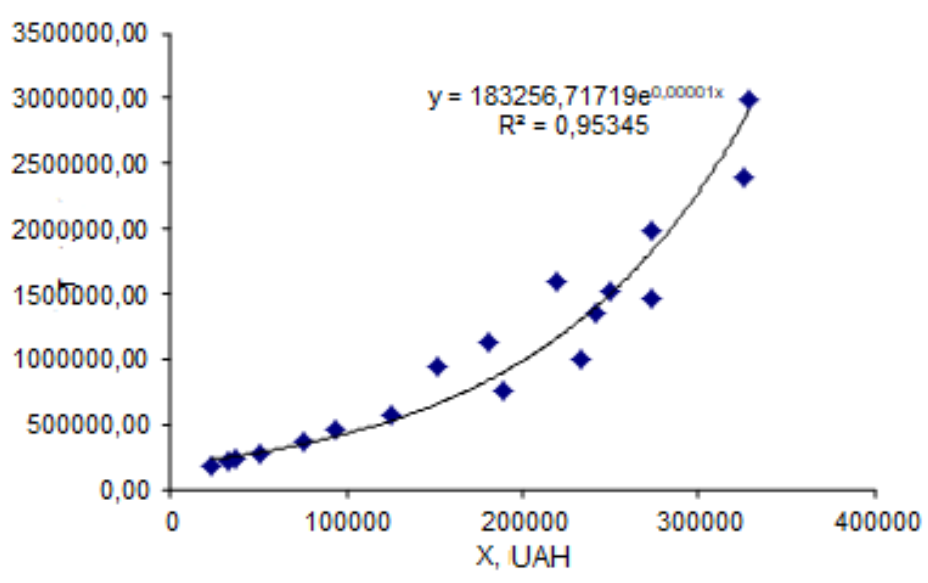

- GDP, mln. UAH

- Exponential (GDP, mln. $\mathrm{UAH}$ )

Fig. 2. The results of the regression analysis on the formation of investments impact trend in capital assets on GDP

As a result of software products use and appliance of dependencies of linear, logarithmic, polynomial, exponential, power characters, it was determined that the exponential function most of all reflects the 
relationship between the investment impact on GDP based on the coefficient RI $=0.955345$ determination which is the largest for this particular function. Further analysis found that the calculated Fisher's ratio test is 134.19 , which is significantly higher than the tabular value of 4.45, so the constructed model is adequate for statistics data and suitable for further analysis and forecasting.

The correlation coefficient for the impact of investments in capital assets on GDP is calculated using the predefined function of the Microsoft Excel program, in accordance with $\mathrm{r} 1[\mathrm{x}, \mathrm{y}]=0.97645$. Whereas $\mathrm{r}[\mathrm{x} ; \mathrm{c}]>0$, then the connection between $\mathrm{X}$ and $\mathrm{Y}$ is direct, and with an increase of investments in capital assets, the GDP of our country will increase, considering the fact that $0.7<|\mathrm{r}[\mathrm{x}, \mathrm{y}]|<1$, then the connection between $\mathrm{X}$ and $\mathrm{Y}$ is strong. Let us evaluate the effect of the variation of factor $\mathrm{X}$ on the variation of indicator $\mathrm{Y}$, using the determination coefficient, that is $0.95345 \%$, the variation of the indicator by $95.35 \%$ is due to the variation of the factor.

The analysis results showed a significant impact of investment on the development of economic potential of our country and GDP growth, therefore, it is necessary to use all the organizational and institutional directions of optimization of Ukraine's positions in international investment activities to increase incoming investment flows. Ukraine has a certain degree of attractiveness to foreign investors, it does not stay aside from world developments, but it is sufficiently integrated into the world economy, however, the disfunction of macrostability, distrust of the neighboring states, corruption, political upheavals, a "hybrid war" with the Russian Federation, the annexation of the Autonomous Republic of Crimea has echo in Ukraine and these are real obstacles for foreign investment. These processes are reflected on the position of Ukraine in international ratings, despite the fact that foreign investors make investment decisions.

\section{Institutional effectiveness of the domestic policy of foreign investment attraction}

Institutional effectiveness of the domestic policy of foreign investment attraction is reflected on the basis of indicators that formed the basis for the creation of international ratings for economic liberty, easiness of setting up and running a business, an integrated index of competitiveness and the index of investment attractiveness of Ukraine as a whole. The methodology of rating coefficients calculation standardizes approaches for determination the potential of all countries and allows to identify sensible parts in the development of organizational and institutional mechanisms for optimizing the position of the country in international investment 
activity. This makes possible to create effective target instruments in improving of the positions in ratings, which are weak least of all.

In table 3, we will consider the dynamics of Ukraine's position in international ratings, that certify the comparative level of institutional effectiveness of country investment policy.

Table 3

\section{POSITION OF UKRAINE IN INTERNATIONAL RATINGS THAT REFLECT THE INSTITUTIONAL EFFECTIVENESS OF DOMESTIC POLICY OF FOREIGN INVESTMENTS ATTRACTION}

\begin{tabular}{|c|c|c|c|c|c|c|c|}
\hline \multirow{2}{*}{ Year } & \multicolumn{2}{|c|}{$\begin{array}{l}\text { Rating of economy } \\
\text { liberty }^{29}\end{array}$} & \multirow{2}{*}{$\begin{array}{c}\text { Raking of } \\
\text { easiness of } \\
\text { running a } \\
\text { business }^{30}\end{array}$} & \multirow{2}{*}{$\begin{array}{c}\text { Credit rating of } \\
\text { Moody's } \\
\text { Investors } \\
\text { Service } \\
\text { Agency }^{31}\end{array}$} & \multirow{2}{*}{$\begin{array}{c}\text { Global } \\
\text { Competitiven } \\
\text { ess Index } \\
\text { position } \\
\text { among an } \\
\text { average of } \\
140 \text { countries }\end{array}$} & \multicolumn{2}{|c|}{$\begin{array}{c}\text { Index of investment } \\
\text { attractiveness of } \\
\text { Ukraine }^{33}\end{array}$} \\
\hline & figure & $\begin{array}{c}\text { change, } \\
\%\end{array}$ & & & & $\begin{array}{l}\text { At the } \\
\text { end of } \\
\text { year }\end{array}$ & $\begin{array}{c}\text { an } \\
\text { absolute } \\
\text { change }\end{array}$ \\
\hline 2007 & 51.5 & - & 139 & - & 69 & - & - \\
\hline 2008 & 51.0 & -0.97 & 145 & - & 73 & - & - \\
\hline 2009 & 48.8 & -4.31 & 142 & - & 72 & 2.57 & - \\
\hline 2010 & 46.4 & -4.92 & 147 & - & 82 & 3.28 & 0.71 \\
\hline 2011 & 45.8 & -1.29 & 145 & - & 89 & 2.56 & -0.72 \\
\hline 2012 & 46.1 & 0.66 & 152 & - & 82 & 2.12 & -0.44 \\
\hline 2013 & 46.3 & 0.43 & 137 & - & 73 & 1.81 & -0.31 \\
\hline 2014 & 49.3 & 6.48 & 112 & $\begin{array}{c}\text { Caa } 3 \text {, stable } \\
\text { estimate }\end{array}$ & 84 & 2.50 & 0.69 \\
\hline 2015 & 46.9 & -4.87 & 96 & $\begin{array}{c}\text { Caa 3, stable } \\
\text { estimate }\end{array}$ & 77 & 2.57 & 0.07 \\
\hline 2016 & 46.8 & -0.21 & 83 & $\begin{array}{c}\text { Caa 2, positive } \\
\text { estimate }\end{array}$ & 79 & 2.85 & 0.28 \\
\hline 2017 & 48.1 & 2.78 & 80 & $\begin{array}{c}\text { Caa 2, positive } \\
\text { estimate }\end{array}$ & 85 & 3.03 & 0.18 \\
\hline 2018 & $\begin{array}{c}51.9 \\
\text { Position } \\
\text { No. } 148 \\
\text { from } 178 \\
\text { countries }\end{array}$ & 7.90 & 76 & $\begin{array}{c}\text { Caa 1, stable } \\
\text { estimate }\end{array}$ & 81 & 3.10 & 0.07 \\
\hline
\end{tabular}

29 Ukraine: index of economic freedom. Knoema. URL: https://knoema.ru/atlas/Украина/Индексэкономической-свободы? ga=2.155881272.204584354.1551111127-477900222.1517845736. [In Russian].

${ }^{30}$ The Doing Business Report, 2007-2018. The World Bank. URL: http://russian.doingbusiness.org/ru/rankings

31 Moody's upgraded Ukraine. https://www.rbc.ua/ukr/news/moody-s-povysilo-reyting-ukrainy1545495152.html. [In Ukrainian].

32 Ukraine's position in the global competitiveness index 2017-2018. Economic Discussion Club. http://edclub.com.ua/analityka/pozyciya-ukrayiny-v-reytyngu-krayin-svitu-za-indeksom-globalnoyi

konkurentospromozhnosti-2. [In Ukrainian]; World Economic Forum. https:/www.weforum.org/reports// (дата звернення: 01.03.2019).

33 The index of investment attractiveness of Ukraine is kept in the neutral plane. Fin Post. https://finpost.com.ua/news/9159. [In Ukrainian]. 
The Economic Liberty Rating is one of the important international ratings that takes into account 12 liberties. According to this rating, countries are graded into categories: free economy, mostly free economy, frugally free economy, unfree and depressed economy. Currently our country is in the group of countries with mostly unfree economy. Ukraine is rated as the last among European countries. According to data of 2018, Ukraine ranks $148^{\text {th }}$ position among 178 countries, and its rating is lower than the regional one according to global indicators. According to the research of the Ukrainian Institute for Analysis and Management of Policy, the domestic economy has been extremely shaken by the annexation of the Autonomous Republic of Crimea and the armed conflict in Donbass for the last years but it is noted that Ukraine has achieved a significant progress in reforming - it became more democratic and transparent (this fact is confirmed by the economic liberty rating value increase in 2018 relative to 2017 by $7.9 \%$ ). However, researchers of the center emphasize on the need of anticorruption efforts, capital markets development, privatization of state enterprises and rationalization of legal framework and supremacy of the law ${ }^{34}$.

As we can see from Table 3, Ukraine significantly improved its position on the international rating of running a business easiness for the researched period. Positive changes occurred in 4 of 10 major components of the research. However, when comparing Ukraine with the former socialist bloc countries, there is no reason to be comforted: the conditions of running a business in Ukraine remain one of the worst both in Western and Eastern Europe (according to data of 2018, for example, Belarus ranked $37^{\text {th }}$ position, Georgia $-6^{\text {th }}$ position $)^{35}$. According to this rating, Ukraine ranks the worst positions in terms of connection of the premises to the energy supply systems of Ukraine (position 128), international trade (position 119) ${ }^{36}$. Therefore, we believe that there are some improvements in the business environment in Ukraine, but it is not ideal and not attractive enough for foreign investors, because, as record shows, investment projects in the countries with a rating of easiness of business running that below than $20^{\text {th }}$ position are in disfavor with foreign investors.

Positive estimates for Ukraine are also reflected in the credit rating of Moody's international rating agency, which raised the rating of

\footnotetext{
34 Ukraine in international rankings. Ukrainian Institute for Policy Analysis and Management. https://uiamp.org.ua/ukrayina-v-mizhnarodnih-reytingah [In Ukrainian].

35 Doing Business-2018. Ukraine in the ranking of the World Bank's Ease of Doing Business. Economic Discussion Club. http://edclub.com.ua/analityka/doing-business-2018-ukrayina-v-reytyngu-svitovogo-bankulegkosti-vedennya-biznesu. [In Ukrainian].

36 Ukraine's business climate has improved, but there are no investors: why so? Etcetera. URL: https://uk.etcetera.media/biznes-klimat-v-ukrayini-polipshivsya-ale-investoriv-nemaye-chomu-tak.html. [In Ukrainian].
} 
Ukraine from Caa2 to Caa1. In addition, the estimate on the ratings changed to "stable" from "positive"; factors of positive estimates for Ukraine were also pointed: the achievement of agreement for a new Stand-By Loan Program by Ukraine and IMF; positive expectations on reduction of corruption due to the reforms in the country; increasing of opposition of Ukraine during the conflict with Russia. Among the negative aspects, the credit rating of Ukraine is a significant dependence on IMF financing ${ }^{37}$.

In the rating of Global Competitiveness Index following the results of 2017-2018 years, Ukraine moved up on 4 positions and ranked $81^{\text {st }}$ position among 137 countries of the world ${ }^{38}$. Ukraine has worsened its positions in 4 of $12 \mathrm{key}$ indicators of the index. However, according to the "Institution" component, the positions of Ukraine has been increasing since 2015. Similar trends relate to "Macroeconomic environment" variable. Despite some improvements, Ukraine's positions in the Global Competitiveness Index are far from ideal. The negative factors for business running in our country are: inflation, corruption, political instability, high tax rates, the complexity of tax legislation, instability of governments, inhibit access to finance, inefficient state bureaucracy, foreign exchange market regulation, poor education of workers, poor ethics of the workforce, insufficient ability to innovate, restrictive regulation of the labor market, improper quality of infrastructure, crime and theft, low quality of public health ${ }^{39}$. Probably, most of the negative factors of business running in Ukraine have institutional nature. Accordingly, the institutional effectiveness of domestic economic policy remains quite low compared with developed countries (ten leaders: Switzerland, USA, Singapore, Netherlands, Germany, Hong Kong, Sweden, United Kingdom, Japan and Finland).

According to the results of interrogation of foreign investors in 2018, which is annually held by the European Business Association, Dragon Capital and the Center for Economic Strategies were named "Top 10 obstacles to foreign investment in Ukraine" 40 (fig. 3). Namely: widespread corruption, distrust of the judicial system, unstable monetary and financial systems, monopolization of markets and the conquest of power by magnates, military conflict with Russia, untenable and alterable legislation, repressive actions by law enforcement

\footnotetext{
${ }^{37}$ Moody's upgraded Ukraine's credit rating. Economichna Pravda. 12/23/2018 https:/www.epravda.com.ua/ news/2018/12/23/643847/ [In Ukrainian].

38 Ukraine's position in the global competitiveness index 2017-2018. Economic Discussion Club. http://edclub.com.ua/analityka/pozyciya-ukrayiny-v-reytyngu-krayin-svitu-za-indeksom-globalnoyi konkurentospromozhnosti-2. [In Ukrainian].

${ }^{39}$ Ibid.

${ }^{40}$ Research: Corruption, mistrust of the courts and the financial system are the main brake on investment. Radio freedom. https://www.radiosvoboda.org/a/news-opytuvannia-investoriv/29496035.html. [In Ukrainian].
} 
institutions, restrictions on capital flows and foreign exchange transactions, complex tax administration, revitalization of labor migration.

All of the above makes it possible to make a conclusion about the low efficiency of the domestic policy of foreign investment attraction in the business activities sphere of Ukraine. Under the conditions of an institutionally ineffective investment policy in Ukraine, domestic spheres of business activity receive less investments. Following the adverse investment environment in the absence of a clear specification of property rights, equitable access to resources, distribution of goods, tax burden, etc. there arose a need for fundamental institutional changes for the development of a civilized institutional environment according to world standards and the formation of a favorable investment environment in the country.

The conducted research proves that Ukraine needs modernization of the economy and investment flows in all spheres of economic activity. Industry, construction, transport and communications, health care, ecology - each of these areas requires significant investment. However, the State Budget lacks funds for expenditures in these directions from year to year, so the investment development of our state is substantially inferior to the level of investment development of European countries.

With insufficient investment in the domestic economy, the population has a few score of billions of dollars in cash. It is clear that in such conditions the shadow economy thrives by means of the constant oppression of the formal economy. Supposedly, that there are significant funds, but Ukrainian citizens are reticent to turn their savings into private investment. From our point of view, this may be due to the following reasons:

- firstly, the overwhelming majority of the population's cash funds is not of an investment nature, rather, it acts as "for a rainy day" resource and evens out the flow of consumption in conditions of unstable national currency;

- secondly, the features of the internal investment environment, etc.

The internal investment environment is characterized by many qualitative characteristics, let us focus on only two of them (Fig. 3).

The insufficiency of national investment resources encourages to turn to foreign sources. Since independence till present, the investment environment in Ukraine can be characterized by the words "It would be nice to be the best".

Nobody will deny that over the years of independence, Ukraine was in a state of permanent reform. There is no point to assume that all reforms were flawed. Why is there no positive effect from their 
implementation and there is no improvement in the investment environment in the country? This question is not rhetorical. The answer is in the sequence of operation of such events. One well-planned and implemented reform properly requires the implementation of complementary reforms, carried out in strict sequence (ranking of reforms) and at a certain time.

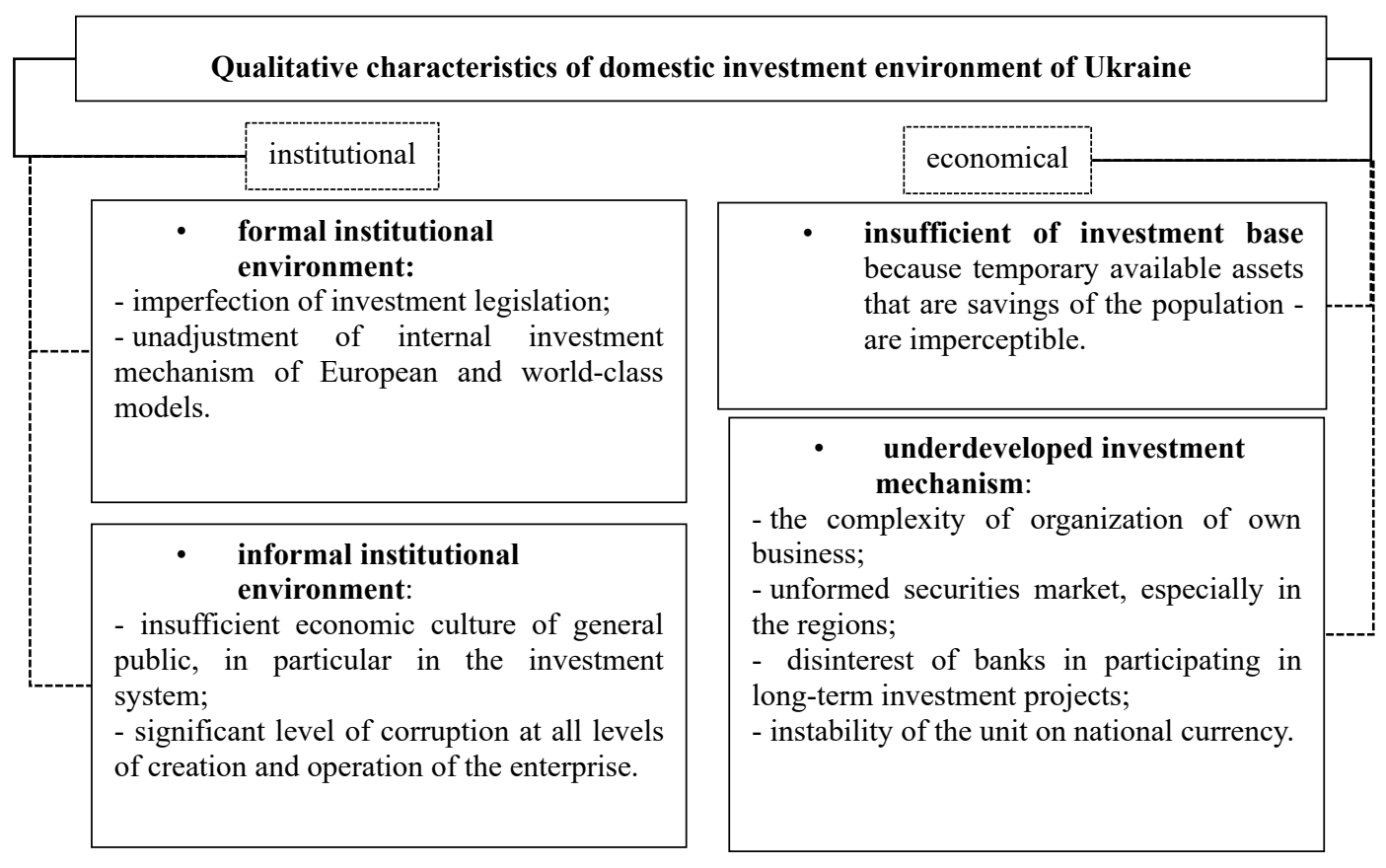

Fig. 3. The main qualitative characteristics of the domestic investment environment of Ukraine ${ }^{41}$

Thus, the main instruments of increasing of the institutional efficiency of investment policy in Ukraine in the context of globalization and internationalization of the world economy should be a real, but no declarative, improvement of the investment environment, reduction of bureaucratic procedures for investors, simplification of regulatory and registration requirements and the adoption of radical measures to efficient protect of the rights of investors. The way out of the situation is the justification of a rational investment policy, in which the system of public regulation and reforming the ownership

${ }^{41}$ Improved based on: Nykytiuk T.L., Baula O.V. Innovatsiino-investytsiinyi rozvytok Ukrainy: suchasni realii ta neobkhidni zminy. Ekonomichnyi chasopys. KhKhI st. 2015. No. 3-4(2). pp.18. [In Ukrainian]. 
structure based on privatization and the concept of technical upgrading of industrial manufacturing with the involvement of foreign investors will have priority ${ }^{42}$.

\section{Development of organizational and institutional conditions of improvement of foreign investment attraction policy effectiveness in Ukraine}

We propose to form the organizational and institutional functions of effectiveness of the domestic policy of investments attraction in Ukraine business activities depending on the Top 10 barriers for foreign investments in Ukraine according to the European Business Association, Dragon Capital and the Center for Economic Strategies, which were discussed above.

Figure 3 shows the organizational and institutional mechanism of effectiveness improvement of the domestic policy of foreign investments attraction in Ukraine's business activities, containing the goals of the domestic investment policy and priority measures to manage organizational, economic and institutional factors for investments attraction.

An investment boom in Ukraine is possible only if a prudent investment policy is implemented, which should contain functions that will give not only a short-run effect, but will be rated for a long-run effect.

A stable national currency is important for the investment capital inflow. A stable national economy is primarily provided by the steadiness of the national currency, which is a consequence of the steadiness of the consumer purchasing power, development of the internal consumption market, growth of the country attractiveness for foreign investors, etc.

Promotion of dividend payment practice and legislatively held responsibility of the issuer for received funds from investors are able to launch the mechanism of stock market instruments using, transformation of personal savings into investment, spreading of fair competition among investors.

${ }^{42}$ Hunko V.I. Osoblyvosti investytsiinoi pryvablyvosti natsionalnoi ekonomiky Ukrainy. Visnyk universytetu bankivskoi spravy Natsionalnoho banku Ukrainy. 2013. No. 3 (18). p.74. [In Ukrainian]. 


\section{THE ORGANIZATIONAL AND INSTITUTIONAL MECHANISM OF EFFECTIVENESS IMPROVEMENT OF THE DOMESTIC POLICY OF FOREIGN INVESTMENTS ATTRACTION IN UKRAINE'S BUSINESS ACTIVITIES}

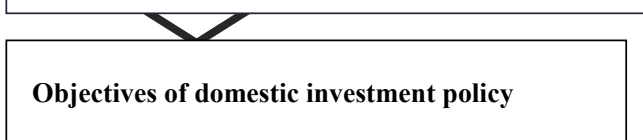

\begin{tabular}{|c|}
\hline $\begin{array}{l}\text { Formation of a clear strategy for ensuring of } \\
\text { sustainable development and economic growth of } \\
\text { the country }\end{array}$ \\
\hline $\begin{array}{l}\text { Formation of an unified management complex in } \\
\text { the investment sphere }\end{array}$ \\
\hline $\begin{array}{l}\text { Formation of an optimal tax system and a system } \\
\text { of tax concession for investors and the state } \\
\text { budget }\end{array}$ \\
\hline $\begin{array}{l}\text { Priority maintenance of investments among } \\
\text { funding resources of business activities }\end{array}$ \\
\hline Formation of a stable financial and banking system \\
\hline Streamlining of investment legislation \\
\hline $\begin{array}{l}\text { Using the potential of the stock market for } \\
\text { investments attraction and improvement of the } \\
\text { country's credit rating }\end{array}$ \\
\hline $\begin{array}{l}\text { Ensuring of public confidence in the reforms in the } \\
\text { country, promoting the conversion of personal } \\
\text { savings into investments }\end{array}$ \\
\hline $\begin{array}{l}\text { Formation of a transparent system of protection of } \\
\text { investors' rights and interests }\end{array}$ \\
\hline $\begin{array}{l}\text { Country insurance against possible negative effects } \\
\text { of foreign investment }\end{array}$ \\
\hline $\begin{array}{l}\text { Clear definition of the priority of investment within } \\
\text { the national economy }\end{array}$ \\
\hline $\begin{array}{l}\text { Using trans-border investment potential of the } \\
\text { country }\end{array}$ \\
\hline
\end{tabular}

Priority management measures for organizational, economic and institutional factors for attraction of investments

Improvement of quality of public administration by implementation of effective system of punishment of unconscionable public employees for acts of corruption and improper performance of their duties, that will act as a motive for foreign investors and citizens for increasing of confidence in the state, and will inhibit the migration of citizens

Spreading of venture investment system involving state funds

Spreading of municipal bond practices for financing of local projects and diaspora bonds for nationwide projects

\begin{tabular}{|c|}
\hline $\begin{array}{l}\text { Ensuring the presentation of the investment potential and } \\
\text { investment offers of the country in the global society }\end{array}$ \\
\hline $\begin{array}{l}\text { Formation of proper transport infrastructure, restoration of } \\
\text { flight connection between the regions of the country (the } \\
\text { important principle in investment is "investments come } \\
\text { where they can be reached") }\end{array}$ \\
\hline $\begin{array}{l}\text { Creating comfortable conditions at the border, } \\
\text { intercalation of a new security system }\end{array}$ \\
\hline $\begin{array}{l}\text { State support for technology incubators which assist } \\
\text { entrepreneurs, engaged in the development and } \\
\text { commercialization of innovative technologies }\end{array}$ \\
\hline $\begin{array}{l}\text { Reforming of judicial and legal authorities for ensuring of } \\
\text { fair trail guarantees and execution of judgments, property } \\
\text { rights protection, protection from raiding }\end{array}$ \\
\hline $\begin{array}{l}\text { Harsher punishment for tax evasion, development of tax } \\
\text { concession system for investors }\end{array}$ \\
\hline
\end{tabular}

Fig. 5. Objectives and measures of the organizational and institutional mechanism of effectiveness improvement of the domestic policy of foreign investments attraction in business activities 


\section{Conclusion}

According to Dragon Capital European Business Association and the Center for Economic Strategies, the biggest obstacle for foreign investment in Ukraine is corruption. An experience of Singapore shows that the existence of strong political will of the country's leadership (an actual intentions of the country's leadership are really, but not declaratively opposed to corruption in all its manifestations) can promote the minimization of corruption. Political will is manifested not only in the private capacity of senior government officials, but also in the level of citizens legal awareness, the development of democratic institutions of society, which ensure the manifestation of such will and its implementation ${ }^{43}$. That is why we believe that it is possible to overcome corruption practices in the country not only by formal legal institutions using, but also by informal ones - changing the consciousness of officials and citizens in the line of intolerance to corruption.

Expansionary measures of the state investment policy of Ukraine should become key at this stage of the domestic economy development.

As can be seen from the above, the main instruments in favorable and efficient investment climate in Ukraine formation should be real, not declarative, reduction of bureaucratic procedures for investors, investments guarantee system reformation, stimulation of the stock market development and its financial instruments taking into account the priority directions of Ukrainian economy development. The proposed organizational and economic mechanism of state regulation of investments attraction will promote a vector approach in favorable organizational, economic and institutional conditions formation for attraction of investments in the domestic economy.

\section{References}

1. Byrka M.I. Teoretyko-metodolohichni pidkhody do analizuvannia priamykh inozemnykh investytsii $v$ konteksti yikh zaluchennia. http://jrnl.nau.edu.ua/index.php/SR/article/view/4701/0 [In Ukrainian].

2. Blank I.A. Capital Management (rus. Upravleniye ispolzovaniyem kapitala). K.: «Nika-Tsentr». 2000. 656 p. [In Russian].

3. Blank. I.A. Financial resources management (rus. Upravleniye finansovymi resursami). M.: Omega-L. Elga. 2011. 768 p. [In Russian].

4. Buzko I.R., Chyzh V.I., Tyshchenko A.Yu. Investytsiina polityka u hlobalnomu vymiri: formuvannia ta realizatsiia: monohrafiia. Skhidnoukr. nats.

${ }^{43}$ Foreign investors fear Ukraine over corruption and raiding - US media. Ukrainian news. 02 Nov.2015. https:/ukranews.com/ua/news/387482-inozemni-investory-boyatsya-ukrainu-cherez-korupciyu-ta-reyderstvoamerykanski-zmi. [In Ukrainian]. 
un-t im. V. Dalia. Luhansk: Vyd-vo SNU im. V. Dalia, 2011. 192 p. [In Ukrainian].

5. Heiets V. Podolannia kvazirynkovosti - shliakh do investytsiino oriientovanoi modeli ekonomichnoho zrostannia. Ekonomika Ukrainy. 2015. No. 6. pp. 4-17. [In Ukrainian].

6. Hunko V.I. Osoblyvosti investytsiinoi pryvablyvosti natsionalnoi ekonomiky Ukrainy. Visnyk universytetu bankivskoi spravy Natsionalnoho banku Ukrainy. 2013. No. 3 (18). p.74. [In Ukrainian].

7. Dashutyna L.O. Osoblyvosti investuvannia transnatsionalnykh korporatsii u mizhnarodnomu biznesi. Visnyk Sumskoho natsionalnoho ahrarnoho universytetu. Seriia : Ekonomika i menedzhment. 2012. Vyp. 8. pp. 179-183. http://nbuv.gov.ua/UJRN/Vsna_ekon_2012_8_40 [In Ukrainian].

8. Doing Business-2018. Ukraine in the ranking of the World Bank's Ease of Doing Business. Economic Discussion Club. http://edclub.com.ua/ analityka/doing-business-2018-ukrayina-v-reytyngu-svitovogo-banku-legkostivedennya-biznesu. [In Ukrainian].

9. Duka A.P. Teoriia ta praktyka investytsiinoi diialnosti. Investuvannia: Navchalnyi posibnyk. K.: Karavela, 2014. 432 p. [In Ukrainian].

10. Gerzanych V.M. Major Disadvantages and Problems of Attracting Foreign Investment in Ukraine // Effective Economics: Electr. Sciences. profession. view. 2014. No. 4. http: / / www.economy.nayka. com.ua/n=4\&y=2014 [In Ukrainian].

11. Foreign direct investment. URL: https://index.minfin.com.ua/en/ economy / fdi / 2018/ [In Ukrainian].

12. Foreign investors fear Ukraine over corruption and raiding - US media. Ukrainian news. 02 Nov.2015. https://ukranews.com/ua/news/387482inozemni-investory-boyatsya-ukrainu-cherez-korupciyu-ta-reyderstvo-amerykanskizmi. [In Ukrainian].

13. Kane, A., Bodie, A.M.Z. Investment Principles. Transl. from eng.. 4 edition. M.: Viliams. 2008. 984 p. [In Russian].

14. Keynes J.M. General theory of employment, interest and money. M :. Helios ARV, 1999.352 p. [In Russian].

15. Kiseleva N.V. Investment activity: a training manual. M.: KNORUS, 2008. 432 p. [In Russian].

16. Kotler F., Kartadzhaiia Kh., Yanh D. Pryvlechenye ynvestorov: marketynhovai pokhod $k$ poysku ystochnykov fynansyrovanyia. Per. s anhl. M.: Alpyna Byznes Buks, 2009. 194 p. [In Russian].

17. Liutak O.M., Voitovych S.Ya., Liakh I.M., Lisovska L.S. Osoblyvosti investytsiinoho zabezpechennia turystychnoi sfery $\mathrm{v}$ umovakh transnatsionalizatsii svitohospodarskykh protsesiv. Finansovo-kredytna diialnist: problemy teorii ta praktyky. - Kharkiv, Universytet bankivskoi spravy. - Vol. 1, No. 24 (2018). pp. 104-112. [In Ukrainian].

18. Lukianenko O.D. Innovatsiini faktory hlobalnoi konkurentospromozhnosti: monohrafiia. K.: KNEU, 2015. 298 p. [In Ukrainian].

19. Lukianenko D., Burmaka M., Halakhova T. Identyfikatsiia kreatyvnykh investytsii $\mathrm{v}$ hlobalnii ekonomitsi. International Economic Policy (ukr. Mizhnarodna ekonomichna polityka). 2016. 2(25). pp. 7-20. [In Ukrainian].

20. Lukianenko D.H., Doroshenko O.S., Halakhova T.O. ta in. Paradyhma kreatyonoho menedzhmentu o hlobalnii ekonomitsi: monohrafiia; za zah. red. d.e.n., prof. D.H. Lukianenka. - K.: KNEU, 2016. Pp. 124-126. [In Ukrainian]. 
21. Lukianenko D. H., Hubskyi B. V., Mozghovyi O. M. ta in. Mizhnarodna investytsiina diialnist: pidruchnyk / za red. D.H.Lukianenka. K.: KNEU, 2003. 387 p. [In Ukrainian].

22. Maiorova T.V., Dyba V.M. Formuvannia investytsiinoho kapitalu v umovakh hlobalnykh vyklykiv. Investytsii: praktyka ta dosvid. 2011. No. 18. pp. 4-8 [In Ukrainian].

23. Makohon Yu.V., Ivankova D.R. Teoretychni aspekty hlobalnoi investytsiinoi diialnosti. Ekonomichnyi visnyk Natsionalnoho tekhnichnoho universytetu Ukrainy «Kyivskyi politekhnichnyi instytut». 2014. No. 11. pp. 481486. http://nbuv.gov.ua/UJRN/evntukpi_2014_11_76 [In Ukrainian].

24. Makohon Yu.V., Lysenko K.V. Ukraine's Investment Attractiveness in Conditions of Global Transformations. Theoretical and practical aspects of intellectual power. 2012. VIP. 1, T. 1. pp. 7-13. [In Ukrainian].

25. Moody's upgraded Ukraine. https://www.rbc.ua/ukr/news/moody-spovysilo-reyting-ukrainy-1545495152.html. [In Ukrainian].

26. Moody's upgraded Ukraine's credit rating. Economichna Pravda. $12 / 23 / 2018$ https://www.epravda.com.ua/news/2018/12/23/643847/ [In Ukrainian].

27. Navrotska N.A. Transformatsiia svitovoho investytsiinoho prostoru $\mathrm{v}$ umovakh hlobalizatsii. Ekonomichnyi chasopys KhKhI st. 2013. No. 3-4 (1). pp. 13-16. URL: http: / / nbuv.gov.ua/UJRN/ecchado 2013 3-4\%281\%29 5 [In Ukrainian].

28. Nykytiuk T.L., Baula O.V. Innovatsiino-investytsiinyi rozvytok Ukrainy: suchasni realii ta neobkhidni zminy. Ekonomichnyi chasopys. KhKhI st. 2015. No. 3-4(2). pp.18. [In Ukrainian].

29. Petkova L.O. Dyversyfikatsiia mizhnarodnykh investytsiinykh stratehii v umovakh hlobalnykh strukturnykh zrushen. Finansovyi prostir. 2012. No. 4 (8). pp. 45-48. [In Ukrainian].

30. Porter, M. E. Competitive Strategy: Techniques for Analyzing Industries and Competitors. - New York: The Free Press, 1980 (2nd ed.). New York: Free Press, 1998. 397 p.

31. Poruchnyk A. M., Stoliarchuk Ya. M. Hlobalni imperatyvy transnatsionalizatsii natsionalnykh ekonomik. In: Formuvannia rynkovoi ekonomiky : zb. nauk.prats. Vyp. 22. 2009. pp. 257-279. [In Ukrainian].

32. Poruchnyk A.M., Haidai Yu.V. Formuvannia instytutsiinykh peredumov systemy hlobalnoho upravlinnia. International Economic Policy (ukr. Mizhnarodna ekonomichna polityka). No. 1-2. 2008. pp. 44-87. [In Ukrainian].

33. Research: Corruption, mistrust of the courts and the financial system are the main brake on investment. Radio freedom. https://www.radiosvoboda.org/ a/news-opytuvannia-investoriv/29496035.html. [In Ukrainian].

34. Revutska N. Suchasni instrumenty zaluchennia inozemnoho kapitalu. Tsinni papery Ukrainy. 2014. No 9. pp. 54-58. [In Ukrainian].

35. Sharp W.F., Alexander G.J., Bailey J.V. Investments. M .: Infra-M, 2001.1028 p. [In Russian].

36. State Statistics Committee named the leading countries for investments in Ukraine.https: / / www.rbc.ua / eng / news / gosstat-nazval-strany-lidery-

investitsiyam-1551374343.html. [In Ukrainian].

37. State Statistics Service. Economic statistics. Foreign economic activity. Investment in foreign economic activity. http://www.ukrstat.gov.ua/ [In Ukrainian]. 
38. The Doing Business Report, 2007-2018. The World Bank. http:// russian.doingbusiness.org/ru/rankings

39. The index of investment attractiveness of Ukraine is kept in the neutral plane. Fin Post. https: / / finpost.com.ua/news/9159. [In Ukrainian].

40. Thompson Jr. Arthur A., Strickland III A.J. Strategic Management. Concepts and situations for analysis. M .: Publishing. Williams House, 2006. 928 p. [In Russian].

41. Ukraine: index of economic freedom. Knoema. URL: https: / / knoema.ru atlas / Украина / Индекс-экономической-свободы?_ga=2.155881272.204584354. 1551111127-477900222.1517845736. [In Russian].

42. Ukraine in international rankings. Ukrainian Institute for Policy Analysis and Management. https://uiamp.org.ua/ukrayina-v-mizhnarodnih-reytingah [In Ukrainian].

43. Ukraine's business climate has improved, but there are no investors: why so? Etcetera. URL: https:/ / uk.etcetera.media/biznes-klimat-v-ukrayinipolipshivsya-ale-investoriv-nemaye-chomu-tak.html. [In Ukrainian].

44. Ukraine's position in the global competitiveness index 2017-2018. Economic Discussion Club. http://edclub.com.ua/analityka/pozyciya-ukrayinyv-reytyngu-krayin-svitu-za-indeksom-globalnoyi -konkurentospromozhnosti-2. [In Ukrainian].

45. Ukraine's State Statistics Committee Data. http://www.ukrstat. gov.ua/ [In Ukrainian].

46. Vovchak O.D., Rushchyshyn N.M., Andrushkiv I.P., Buchko I.Ye. Investytsiine kredytuvannia: navch. posib. 2-he vyd., pererobl. i dopovn. K.: Znannia, 2013. 227 p. [In Ukrainian].

47. Why foreign investments are in no hurry to Ukraine. URL: https: / / minfin.com.ua/en /2019/05/14/37746973/. [In Ukrainian].

48. World Economic Forum. https://www.weforum.org/reports//

The article was received by the Editorial Board on August 13, 2019. 